\title{
Enhancement the Productivity of some Rice Varieties by Using Some Growth Promoter Supplements
}

\author{
Talha, I.A. ${ }^{1}$, M.A.Gomma ${ }^{1}$, A.M. Nada ${ }^{1}$ and Dalia, M. Tabl ${ }^{2}$
}

\begin{abstract}
Biostimulants are products that enhancement the fertilizers and elements use efficiency then increase plant growth, tolerant to water deficit and abiotic stresses. In small concentrations, these substances are efficient, favoring the good performance of the plant's vital processes, and allowing high yields and good quality products. The present investigation was carried out in the experimental farm of Rice Research Department - Sakha Agriculture Research Station, FCRI, ARC, Egypt during 2019 and 2020 seasons. The objectives of this presentation, study the effect of growth promoter supplements on growth and agronomic traits and rice yield, as well as, relationship among grain yield and other studied traits with the different sources of growth promoter supplement for each studied varieties. Nine rice varieties were evaluated under three growth promoter supplements of foliar spraying of viusid agro, alfarid 1 and humic plus. A split-plot design in a randomized complete block design was used with three replications. The main plots were devoted to growth promoter supplement While, sub plots were devoted to rice varieties. The remains cultural practices were applied as recommended by RRTC. Data were recorded on $25 \mathrm{plant} / \mathrm{m}^{2}$ which were taken from plot the following traits, as recommended by standard Evaluation System (SES) of IRRI. Results showed that, there were highly significantly between growth promoter supplement and rice varieties for all the studied traits, whereas, the desirable values recorded for yield and its component with viusid agro followed by alfarid 1compared to control . Grain yield with treated by the viusid agro was significantly exceeded control treatment by $(23.09 \%)$. Yield increasing due to viusid agro was accompanied by significant increasing in number of panicles plant $^{-1}$ (26.44\%), 1000 grain weight $(8.40 \%)$ compared with control treatment. This study concluded that, increasing rice grain yield and related traits were obvious for most studied varieties by applying the growth promoter supplement of viusid agro or alfarid 1 for the hybrids rice SK2034H and SK2003H under the irrigation every eight days, as used for this study.
\end{abstract}

Keywords: Biostimulants, Viusid Agro, Alfarid 1 humic plus and RRTC

\section{INTRODUCTION}

Rice (Oryza sativa, L.,) is the primary food source for more than one-half of the world's population.
Because rice cultivation is dependent on water availability which affect on grain yield.

In order to prevent these losses, biostimulants are increasingly being integrated into production systems with the goal of modifying physiological processes in plants to optimize productivity Yakhin et al., (2017). Biostimulants are products that reduce the need for fertilizers and increase plant growth, tolerant to water and abiotic stresses. In small concentrations, these substances are efficient, favoring the good performance of the plant's vital processes, and allowing high yields and good quality products. In addition, biostimulants applied to plants enhance nutrition efficiency, abiotic stress tolerance and/or plant quality traits, regardless of its nutrient contents.

Water Stress for the plants reduces the plant-cell's water potential and turgor, which elevate solute concentrations in the cytosol and extracellular matrices. As a result, cell enlargement decreases leading to growth inhibition and reproductive failure Du Jardin (2015) which is followed by accumulation of abscisic acid (ABA) and compatible osmolytes like proline, which cause wilting. Drought not only affects plantwater relations through the reduction of water content, turgor and total water, but it also affects stomatal closure, limits gaseous exchange, reduces transpiration and arrests carbon assimilation (photosynthesis) rates Yakhin et al., (2017). Negative effects on mineral nutrition (uptake and transport of nutrients) and metabolism leads to a decrease in the leaf area and alteration in assimilate partitioning among the organs. Plant responses to water stress condition are complex and several different mechanisms are adopted by plants when they encounter drought Basak (2008) and Bulgari et al., (2015) including: (i) drought escape by rapid development which allows plants to finish their cycle before severe water stress; (ii) drought avoidance by, for instance, increasing water uptake and reducing transpiration rate by the reduction of stomatal conductance and leaf area; (iii) drought tolerance by maintaining tissue turgor during water stress via osmotic adjustment which allows plants to maintain growth under water stress, and (iv) resisting severe stress through other survival mechanisms Basak (2008).

DOI: $10.21608 / A S E J A I Q J S A E .2020 .139370$

${ }^{1}$ Rice Research Department, Field Crops Research Institute,

Agriculture Research Center, Egypt.

${ }^{2}$ Rice Technology and Training Center, Field Crops Research Institute, Agriculture Research Center, Egypt.

Received December 05, 2020, Accepted, December 30, 2020 
Water stress reduces the rice growth, and severely affects the seedling biomass, photosynthesis, stomatal conductance, plant water relations and starch metabolism Du Jardin (2012). Depending on timing, duration and severity of the plant water deficit, the grain yield of some rice genotypes could be reduced by up to $81 \%$ under drought Couto et al (2012). The application of periodical water stress and potassium fertilization has been reported to induce tolerance of rice to osmotic stress Yakhin et al., (2017). Numerous studies have shown that the application of $\mathrm{K}$ fertilizer mitigates the adverse effects of drought on plant growth Amin et al., (2011) and Forde and Lea (2007). Potassium increases the plant's drought tolerant through its functions in stomatal regulation, osmoregulation, energy status, charge balance, protein synthesis, and homeostasis Robinson et al., (1991). In plants coping with water stress, the accumulation of $\mathrm{K}^{+}$may be more important than the production of organic solutes during the initial adjustment phase, because osmotic adjustment through ion uptake like $\mathrm{K}+$ is more energy efficient Rhods et al., (1986). Lea et al., (2007) have reported that lower water loss in plants well supplied with $\mathrm{K}^{+}$is due to a reduction in transpiration which not only depends on the osmotic potential of mesophyll cells, but also is controlled to a large extent by opening and closing of stomata. Water deficit for plant cells leads to a reduction in carbon assimilation, which is linked to a physiological closure of leaf stomata and to biochemically determined lower photosynthetic activity, which affects carbohydrate economy Van Oosten et al., (2017). Sucrose plays an important role in plant metabolism at both cellular and whole organism level. It participates not only in the response to abiotic stresses, but also serves as a nutrient and signaling molecule, modulating a wide range of gene activity Lana (2009).

Biostimulants are natural or synthetic substances that can be applied to seeds, plants, and soil. These substances cause changes in vital and structural processes in order to influence plant growth through improved tolerance to abiotic stresses and increase seed and/or grain yield and quality. In addition, biostimulants reduce the need for fertilizers Du Jardin (2015).

In general, biostimulants are produced as a junction of natural or synthetic substances composed of hormones or precursors of plant hormones. When applied correctly in the crops, it acts directly on the physiological processes providing potential benefits for growth, development, and/or responses to water stress, saline, and toxic elements, such as toxic aluminum Du Jardin (2012) and Couto et al (2012). These products, which differ from traditional nitrogen, phosphorus, and potassium fertilizers, may contain in their formula a variety of organic compounds, such as humic acids, seaweed extracts, vitamins, amino acids, ascorbic acid, and other chemicals, which may vary according to its manufacturer Yaronskaya et al., (2006). Biostimulants offer a potentially novel approach for the regulation and/or modification of physiological processes in plants to stimulate growth, to mitigate stress induced limitations, and to increase yield. The effects of biostimulants are still not clear. They can act on plant productivity as a direct response of plants or soils to the biostimulant application or an indirect response of the biostimulant on the soil and plant microbiome with subsequent effects on plant productivity Yakhin et al., (2017).

Therefore the objectives of the present study were: (i) to study the effect of growth promoter supplement of rice varieties on agronomic and rice yield traits under irrigation eight days (ii) to determine the optimal growth promoter supplement which improve grain yield in rice varieties studied (iii) to study relationship among grain yield and other traits of studied varieties with different sources of growth promoter supplement.

\section{MATERIALS AND METHODS}

This experiment was carried out at Experimental Farm of the Rice Research and Training Center, Sakha Agriculture Research Station, Kafr El-Sheikh, Egypt $\left(\left(31^{\circ} 05^{\prime} 17^{\prime \prime} \mathrm{N} 30^{\circ} 56^{\prime} 44^{\prime \prime} \mathrm{E}\right.\right.$, with an altitude of 7 meter $)$ during the two successive seasons on 2019 and 2020. The climatic variables in the two successive seasons are presented in Table 1. Soil properties in 2019 and 2020 seasons are presented in Table 2.

\section{Plant material}

The genetic materials used in this investigation included Nine rice varieties, namely GZ10101, GZ10154, GZ10365, MJ5460, Giza 178, Giza 179, Sakha 104, SK2034H and SK2003H were used in this investigation. The pedigree and origin of these varieties as presented in (Table 3).

\section{Experimental design and treatments:}

A split-plot design in a randomized complete block arrangement was used with three replications. The main plots were allotted to the three growth promoter supplement with foliar spraying the composition of viusid agro $\left(\mathrm{T}_{1}\right)$, alfarid1 $\left(\mathrm{T}_{2}\right)$, humic plus $\left(\mathrm{T}_{3}\right)$ in addition control treatment (water spraying) are presented in Table 4, while, rice varieties were devoted to sub-plot. The date of sowing was in $1^{\text {st }}$ May during 2019 and 2020 seasons and then the rice varieties were transplanted in seven rows with $5 \mathrm{~m}$ long as individual plants with plant spacing $20 \times 20 \mathrm{~cm}$, the rice varieties were grown in a Randomized Complete Block Design (RCBD) with three replications. This experiment was under water deficit condition with irrigated every 8 days. The growth promoter supplements were applied by foliar spraying twice times (at maximum tillering and 
booting stage). All recommended cultural practices for rice cultivation were applied as recommended by RRTC (2018). Data were recorded on 25 randomly selected plants from each replication and mean values were used for statistical analysis. In this study fifteen morphological, yield and grain quality traits include, days to heading (day), plant height $(\mathrm{cm})$, flag leaf area $\left(\mathrm{cm}^{2}\right)$, number of panicles per plant, panicle length $(\mathrm{cm})$, panicle weight $(\mathrm{g})$, number of filled grains per panicle, seed set $(\%), 1000$ grain weight $(\mathrm{g})$, grain yield ( $\mathrm{t} / \mathrm{fed}$.) and harvest index (\%), hulling (\%), milling (\%), head rice $(\%)$ and amylose content $(\%)$ as recommended by Standard Evaluation System (SES) of IRRI (2008).

Table 1. Monthly maximum and minimum temperature $\left(\mathrm{C}^{0}\right)$, relative humidity $\%$ and wind velocity $(\mathrm{Km} / \mathrm{h})$ at RRTC Sakha, Kafr EL Skeikh province during 2019 and 2020 seasons

\begin{tabular}{ccccccccccc}
\hline Month & \multicolumn{3}{c}{ 2019 season } & \multicolumn{3}{c}{ 2020 season } \\
\hline & $\begin{array}{c}\text { Temperature } \\
\left(\mathbf{C}^{\mathbf{0}}\right)\end{array}$ & $\begin{array}{c}\text { Relative Humidity } \\
(\boldsymbol{\%})\end{array}$ & $\begin{array}{c}\text { Wind } \\
\text { Velocity } \\
(\mathbf{K m} / \mathbf{h})\end{array}$ & $\begin{array}{c}\text { Temperature } \\
\left(\mathbf{C}^{\mathbf{0}}\right)\end{array}$ & $\begin{array}{c}\text { Relative } \\
\text { Humidity } \mathbf{( \% )})\end{array}$ & $\begin{array}{c}\text { Wind } \\
\text { Velocity } \\
(\mathbf{K m} / \mathbf{h})\end{array}$ \\
\hline April & $\mathbf{M a x}$ & $\mathbf{M i n}$ & $\mathbf{7 . 3 0}$ & $\mathbf{1 3 . 0 0}$ & & $\mathbf{M a x}$ & $\mathbf{M i n}$ & $\mathbf{7 . 3 0}$ & $\mathbf{1 3 . 0 0}$ \\
May & 30.19 & 13.7 & 78.30 & 48.50 & 95.70 & 30.03 & 18.62 & 81.60 & 41.80 & 87.10 \\
June & 30.85 & 21.14 & 77.30 & 46.10 & 114.60 & 30.40 & 22.80 & 71.00 & 45.80 & 97.00 \\
July & 33.00 & 22.40 & 85.20 & 51.20 & 105.30 & 33.60 & 26.30 & 75.70 & 46.60 & 112.80 \\
August & 35.10 & 25.00 & 83.8 & 51.70 & 97.30 & 33.70 & 26.10 & 82.70 & 56.80 & 105.50 \\
Sept. & 34.60 & 23.80 & 82.70 & 46.50 & 95.30 & 32.60 & 26.0 & 84.30 & 56.30 & 92.80 \\
Oct. & 29.90 & 20.60 & 80.90 & 54.10 & 87.00 & 29.8 & 21.70 & 83.10 & 51.80 & 95.30 \\
\hline
\end{tabular}

Table 2. Soil mechanical and chemical analysis of the experimental site

\begin{tabular}{ccc}
\hline Soil analysis & $\mathbf{2 0 1 9}$ & $\mathbf{2 0 2 0}$ \\
\hline Mechanical analysis & & \\
Clay \% & 59.70 & 58.83 \\
Silt \% & 29.10 & 30.30 \\
Sand \% & 10.50 & 10.87 \\
Texture class & Clay & Clay \\
Chemical analysis & & \\
\hline Organic matter\% & 1.55 & 1.50 \\
E.C. (ds/m) & 2.00 & 2.03 \\
PH & 8.10 & 8.14 \\
Total N ppm & 450 & 475 \\
Available P ppm & 14.3 & 16.5 \\
Available K ppm & 325 & 326 \\
Available Zn ppm & 0.87 & 0.89 \\
\hline
\end{tabular}

Table 3. The studied nine rice genotypes with their pedigree and origin

\begin{tabular}{cccc}
\hline No. & Entry. & Pedigree & Origin \\
\hline 1 & GZ10101 & Sakha 103 x IR385 & Egypt \\
2 & GZ10154 & Sakha 105 x Sakha 101 & Egypt \\
3 & GZ10365 & BY-GC-30 x SKC 23822 & Egypt \\
4 & MJ5460 & Unknown & China \\
5 & Giza 178 & Giza 175/Millyang 49 & Egypt \\
6 & Giza 179 & GZ1368-5-5-4/GZ6296 & Egypt \\
7 & Sakha 104 & GZ4096/ GZ4100 & Egypt \\
8 & SK2034H & IR69625A x Giza 178 & Egypt \\
9 & SK2003H & G46A x Giza 178 & Egypt \\
\hline
\end{tabular}


Table 4. Chemical components \% of Viusid agro, AlFarid 1 and Humic plus used in 2019 and 2020 seasons

\begin{tabular}{|c|c|c|c|c|c|c|}
\hline \multirow[t]{2}{*}{ No. } & \multicolumn{6}{|c|}{ Components } \\
\hline & Viusid Agro $\left(T_{1}\right)$ & Conc. & Alfarid1( $\left.T_{2}\right)$ & Conc. & Humic plus $\left(\mathbf{T}_{3}\right)$ & Conc. \\
\hline 1 & Potassium phosphate & $5.00 \%$ & Amino Acids & $19.47 \%$ & Nitogen & $10 \%$ \\
\hline 2 & Malic acid & $4.60 \%$ & Nitrogen & $10 \%$ & Potassium & $8 \%$ \\
\hline 3 & Glucosamine & $4.60 \%$ & Potassium & $8 \%$ & Magnesium & $1 \%$ \\
\hline 4 & Arginine & $4.15 \%$ & Magnesium & $1 \%$ & Copper & 600ppm \\
\hline 5 & Glycine & $2.35 \%$ & Iron Chelated & $3000 \mathrm{ppm}$ & Iron Chelated & $5000 \mathrm{ppm}$ \\
\hline 6 & Ascorbic acid & $1.15 \%$ & Zinc Chelated & $1500 \mathrm{ppm}$ & Zinc Chelated & $5000 \mathrm{ppm}$ \\
\hline 7 & Calcium pantothenate & 0.115 & $\begin{array}{l}\text { Manganese } \\
\text { Chelated }\end{array}$ & 500 ppm & Boron Chelated & $400 \mathrm{ppm}$ \\
\hline 8 & Pyridoxal & 0.225 & Boron & 200 ppm & Molybdenum & 200 ppm \\
\hline 9 & Folic acid & 0.05 & Molybdenum & 100 ppm & Sulphur & $2 \%$ \\
\hline 10 & Cyanocobalamin & 0.0005 & - & - & Humic acid & \\
\hline 11 & $\begin{array}{l}\text { Monoammonium } \\
\text { glycyrrizinate }\end{array}$ & 0.23 & - & - & & \\
\hline 12 & Zinc sulphate & 0.115 & - & - & & \\
\hline & $\begin{array}{l}\text { Recommendation } \\
\text { application dose }\end{array}$ & $\begin{array}{c}150 \\
\mathrm{ml} / \mathrm{fed}\end{array}$ & $\begin{array}{l}\text { Recommendation } \\
\text { application dose }\end{array}$ & $1 \mathrm{k} . \mathrm{g} / \mathrm{fed}$ & $\begin{array}{r}\text { Recommendation } \\
\text { application dose }\end{array}$ & $2 \mathrm{~K} . \mathrm{g} / \mathrm{fed}$ \\
\hline
\end{tabular}

The response of studied traits to growth promoter supplement:

Relative change $=(($ Spraying growth promoter supplement - control treatment) / Spraying growth promoter supplement) x 100)

\section{Data Analysis:}

All the morphological, yield and grain quality data collected were subjected to analysis of variance (ANOVA) while significant means were separated with least significant difference (LSD) using Costat software. The collected data were analyzed for analysis of variances according to Gomez and Gomez (1984).

\section{RESULTS AND DISCUSSION}

Results in Table 5 revealed that the effect of different growth promoter supplement and rice varieties as well as, their interaction on days to heading, plant height and flag leaf area. Results showed that the days to heading, plant height and flag leaf area were highly affected by applied growth promoter supplement through two seasons and combined data. The desirable values for the previous traits were recorded with the viusid agro and alfarid 1, but, the undesirable values for the same traits were recorded with control treatment (water spraying). Also, the results in the Table 5 clarified that there were a significant differences among the rice varieties in some characters namely days to heading, plant height and flag leaf area. The rice variety Giza 179 recorded the shortest duration for days to heading. The line MJ5460 recorded the shortest stature, whereas, the hybrid SK2003H recorded the highest value for flag leaf area. All the interaction between two factors studied had significant effect on these traits indicating the dependent effect of each one this trait in the two seasons, these results indicated that, biostimulants, especially Viusid agro, and Alfarid 1 play a critical role in the growth and development in rice plant. In addition to, diminish (decrease) the effect of this stress on plants growth. Colla et al., (2015) obtained that, Sustainable agriculture requires using not only effective mineral fertilizers containing macro- and microelements, but also plant growth biostimulants which are a rich source of biologically active compounds. These very important formulations allow achieving significant increases in the quality and quantity of yield, as well as improve the health of plants. Moreover, these preparations improve the efficiency of fertilizer nutrients uptake. Protein hydrolysates are an important group of plant growth biostimulants based on a mixture of peptides and amino acids. Van Oosten et al., (2017) showed that, the biostimulants for improving plant resilience in water limiting environments should stimulate root versus shoot growth, which would allow plants to explore deeper soil layer during the drought season and stimulate the synthesis of compatible solutes to reestablish favorable water potential gradients and water uptake at diminishing soil water. Similar positive effects can be given by those microbial biostimulants that create absorption surfaces around the root systems and sequester soil water in favor of the plants. 
Table 5. Effect the different sources of growth promoter supplement of rice varieties and their interaction on days to heading,plant height and flag leaf area during 2019 and 2020 seasons and combined data

\begin{tabular}{|c|c|c|c|c|c|c|c|c|c|}
\hline \multirow[t]{2}{*}{ Main effect } & \multicolumn{3}{|c|}{ Days to heading (day) } & \multicolumn{2}{|c|}{ Plant height $(\mathrm{cm})$} & \multicolumn{4}{|c|}{ Flag leaf area $\left(\mathrm{cm}^{2}\right)$} \\
\hline & 2019 & 2020 & Combined & 2019 & 2020 & Combined & 2019 & 2020 & Combined \\
\hline \multicolumn{10}{|l|}{ Growth Promoter } \\
\hline \multicolumn{10}{|l|}{ Supplement (G) } \\
\hline Control & 93.56 & 92.59 & 93.07 & 83.43 & 84.25 & 83.85 & 28.22 & 29.25 & 28.74 \\
\hline Viusid agro & 91.81 & 91.37 & 91.59 & 90.59 & 89.44 & 90.02 & 33.08 & 33.05 & 33.06 \\
\hline Alfarid 1 & 92.22 & 91.41 & 91.81 & 90.58 & 89.50 & 90.04 & 34.51 & 35.67 & 35.09 \\
\hline Humic plus & 92.96 & 92.93 & 92.94 & 87.43 & 86.62 & 87.02 & 30.99 & 32.44 & 31.72 \\
\hline LSD 0.05 & 0.337 & 0.457 & 0.196 & 0.679 & 0.462 & 0.353 & 0.559 & 0.817 & 0.630 \\
\hline \multicolumn{10}{|l|}{ Rice Varieties (V) } \\
\hline GZ10101 & 88.08 & 87.75 & 87.92 & 82.05 & 82.00 & 82.03 & 29.45 & 30.03 & 29.75 \\
\hline GZ10154 & 90.50 & 90.17 & 90.33 & 83.21 & 82.67 & 82.94 & 27.92 & 28.53 & 28.22 \\
\hline GZ10365 & 90.67 & 89.41 & 90.04 & 85.63 & 84.66 & 85.15 & 24.73 & 25.36 & 25.05 \\
\hline MJ5460 & 93.58 & 93.50 & 93.54 & 75.93 & 74.79 & 75.36 & 35.47 & 37.79 & 36.64 \\
\hline Giza 178 & 95.75 & 95.66 & 95.71 & 90.12 & 90.33 & 90.23 & 31.53 & 32.25 & 31.89 \\
\hline Giza 179 & 84.92 & 84.41 & 84.67 & 84.72 & 83.83 & 84.28 & 34.23 & 35.07 & 34.65 \\
\hline Sakha 104 & 95.67 & 95.08 & 95.38 & 98.08 & 97.25 & 97.67 & 27.70 & 28.12 & 27.92 \\
\hline SK2034H & 96.83 & 95.75 & 96.29 & 95.22 & 94.29 & 94.75 & 34.19 & 34.72 & 34.46 \\
\hline SK2003H & 97.75 & 96.91 & 97.33 & 97.13 & 97.27 & 97.20 & 40.04 & 41.55 & 40.80 \\
\hline LSD 0.05 & 0.597 & 0.651 & 0.479 & 0.804 & 0.461 & 0.743 & 1.180 & 1.271 & 0.979 \\
\hline \multicolumn{10}{|l|}{ Interaction } \\
\hline $\mathrm{G} \times \mathrm{V}$ & $* *$ & $* *$ & $* *$ & $* *$ & $* *$ & $* *$ & $* *$ & $* *$ & $* *$ \\
\hline
\end{tabular}


Results in Table 6 revealed the effect of the interaction between growth promoter supplement and rice varieties on morphological traits. The results showed that, days to heading, plant height and flag leaf area were highly affected by growth promoter supplement and rice varieties during two seasons (combined data), the desirable value for the days to heading were (83.33 day) with the alfarid 1 of the rice variety Giza 179 during two seasons, while, the undesirable values for days to heading recorded ( 98.50 day) with the humic plus for the promising hybrid SK2003H during two seasons. Also, plant height was highly affected by growth promoter supplement and rice varieties during two seasons, the highest value for the plant height were $(100.17 \mathrm{~cm})$ with the viusid agro of Sakha $104(100.00 \mathrm{~cm})$ during two seasons, while, the lowest value for plant height recorded $(65.00 \mathrm{~cm})$ with control treatment (without spraying) of the line MJ 5460 during two seasons. Concerning flag leaf area, affected by growth promoter supplement and rice varieties during two seasons, whereas, the highest value for flag leaf area recorded $\left(42.62\right.$ and $\left.42.34 \mathrm{~cm}^{2}\right)$ with the alfarid 1 and viusid agro of the hybrid rice SK2003H during two seasons, but, the lowest value for flag leaf area recorded $\left(20.92 \mathrm{~cm}^{2}\right)$ with control treatment (without spraying) of the promising line GZ10365 during two seasons. Amino acids that involved in the components of viusid agro have several roles in plants, such as they have positive effects on plant growth and yields as well as helping the plants to overcome the harmful effect caused by abiotic stress (Kowalezky and Zielong, 2008). In addition, they regulate ion transport and stomatal opening and affect the synthesis and activity of enzymes and gene expression (Rai, 2002).

Results in Table 7 revealed that, effect the different growth promoter supplement and rice varieties as well as, their interaction on number of panicles per plant ${ }^{-1}$, panicle length, panicle weight and number of filled grains per panicle during two seasons and combined data. Results showed that the number of panicles per plant $^{-1}$, panicle length, panicle weight and number of filled grains per panicle were highly affected by different growth promoter supplement through two seasons. The desirable values for the previous traits were recorded with viusid agro and alfarid 1, but, the undesirable values for the same traits were recorded with control treatment (without spraying). Also, the results in the Table 7 clarified that there were a significant differences among the rice varieties in some characters namely number of panicles plant $^{-1}$, panicle length, panicle weight and number of filled grains per panicle, the hybrid SK2003H recorded the highest values for number of panicles plant ${ }^{-1}$, panicle length and weight and number of filled grains panicle ${ }^{-1}$, these results indicated that biostimulants, specifically Alfarid
1 and viusid agro play a critical role in the growth and development in rice plant. All the interaction between two factors studied had significant effect on these traits indicating the dependent effect of each one this trait in the two seasons. Paleckiene et al (2007) reported that, the use of amino acids is most often recommended under critical conditions of plant growth: after transplantation, in the flowering period and during climatic stresses (night frosts and drought) or plant diseases.

Results in Table 8 revealed the effect of the interaction between growth promoter supplement and rice varieties on some yield traits. The results showed that, number of panicles plant ${ }^{-1}$, panicle length, panicle weight and number of filled grains panicle ${ }^{-1}$ were highly affected by growth promoter supplement and rice varieties during two seasons (combined), the desirable value for the number of panicles plant ${ }^{-1}$ were (19.68) for the viusid agro with the hybrid rice SK2034H during two seasons, while, the lowest value for number of panicles plant ${ }^{-1}$ recorded with control treatment for the line MJ5460 which recorded (9.23) during two seasons.

Also, panicle length was highly affected by growth promoter supplement and rice varieties during two seasons, the desirable value for the panicle length were $(24.13 \mathrm{~cm})$ with the alfarid 1 of the hybrid $2003 \mathrm{H}$ during two seasons, while, the un desirable value for panicle length recorded with the control treatment of the line MJ5460 which recorded $(15.28 \mathrm{~cm})$ during two seasons.

Concerning panicle weight, affected by growth promoter supplement and rice varieties during two seasons, the highest value for panicle weight recorded with the alfarid 1 of the line MJ5460 (4.99 g) during two seasons, but, the lowest value for panicle weight with control treatment of the promising line GZ10101 which recorded $(2.71 \mathrm{~g})$ during two seasons.

With respect to, number of filled grains panicle ${ }^{-1}$ was highly affected by growth promoter supplement and rice varieties during two seasons, the desirable value for the number of filled grains per panicle were (168.00) with the alfarid 1 of the hybrid $2003 \mathrm{H}$ during two seasons, while, the un desirable value for number of filled grains per panicle recorded (91.00) with the control treatment of the promising line GZ10101 during two seasons. Jan and Parray (2016) showed that, amino Prim is a typical amino acid plant growth biostimulant with the total amount of macroelements $(\mathrm{N}, \mathrm{P}, \mathrm{K}, \mathrm{Ca}$, $\mathrm{Mg}$, and $\mathrm{S}$ ) of $16.5 \%$ and the small content of microelements (B, Cu, Fe, Mn, Mo, and $\mathrm{Zn}$ ) of $0.27 \%$. In the case of AminoHort, these values are as follows: macroelements $20.5 \%$ and microelements $2.1 \%$. This biostimulant can also supply cultivated plants (beside ready building blocks, i.e. amino acids) with elements in 
the case of their critical deficiencies. Amino acids are known to facilitate the transport of elements (metal translocation through xylem).

Table 6. The effect of the interaction between growth promoter supplement and rice varieties on days to heading (day), plant height $(\mathrm{cm})$ and flag leaf area $\left(\mathrm{cm}^{2}\right)$ for combined data

\begin{tabular}{|c|c|c|c|c|}
\hline \multirow{2}{*}{$\begin{array}{l}\text { Growth Promoter } \\
\text { Supplement (G) }\end{array}$} & \multirow[t]{2}{*}{ Rice Varieties (V) } & $\begin{array}{l}\text { Days to heading } \\
\text { (day) }\end{array}$ & $\begin{array}{l}\text { Plant height } \\
(\mathrm{cm})\end{array}$ & $\begin{array}{c}\text { Flag leaf area } \\
\left(\mathrm{cm}^{2}\right)\end{array}$ \\
\hline & & Comb. & Comb. & Comb. \\
\hline \multirow{9}{*}{ Control } & GZ10101 & 92.17 & 80.83 & 26.43 \\
\hline & GZ10154 & 95.83 & 81.96 & 26.09 \\
\hline & GZ10365 & 91.33 & 79.50 & 20.92 \\
\hline & MJ5460 & 93.17 & 65.00 & 30.58 \\
\hline & Giza 178 & 94.83 & 82.83 & 26.96 \\
\hline & Giza 179 & 85.67 & 78.08 & 33.66 \\
\hline & Sakha 104 & 93.83 & 96.66 & 25.52 \\
\hline & SK2034H & 94.33 & 93.23 & 31.63 \\
\hline & SK2003H & 96.50 & 96.50 & 36.90 \\
\hline \multirow{9}{*}{ Viusid agro } & GZ10101 & 86.17 & 83.00 & 30.62 \\
\hline & GZ10154 & 88.16 & 84.13 & 29.02 \\
\hline & GZ10365 & 89.50 & 86.42 & 25.40 \\
\hline & MJ5460 & 92.00 & 77.76 & 35.53 \\
\hline & Giza 178 & 96.17 & 94.90 & 31.72 \\
\hline & Giza 179 & 84.16 & 89.93 & 35.63 \\
\hline & Sakha 104 & 95.66 & 100.17 & 32.44 \\
\hline & SK2034H & 95.67 & 96.00 & 34.87 \\
\hline & SK2003H & 96.83 & 97.83 & 42.34 \\
\hline \multirow{9}{*}{ Alfarid1 } & GZ10101 & 85.50 & 82.93 & 30.64 \\
\hline & GZ10154 & 88.00 & 83.83 & 32.96 \\
\hline & GZ10365 & 89.17 & 90.52 & 28.42 \\
\hline & MJ5460 & 95.00 & 83.42 & 42.74 \\
\hline & Giza 178 & 95.67 & 92.67 & 35.93 \\
\hline & Giza 179 & 83.33 & 85.00 & 37.30 \\
\hline & Sakha 104 & 95.17 & 99.50 & 27.81 \\
\hline & SK2034H & 97.00 & 95.37 & 37.38 \\
\hline & SK2003H & 97.50 & 97.16 & 42.61 \\
\hline \multirow{9}{*}{ Humic plus } & GZ10101 & 87.83 & 81.33 & 31.30 \\
\hline & GZ10154 & 89.33 & 81.83 & 24.86 \\
\hline & GZ10365 & 90.16 & 84.16 & 25.46 \\
\hline & MJ5460 & 94.00 & 75.25 & 37.69 \\
\hline & Giza 178 & 96.17 & 90.50 & 32.97 \\
\hline & Giza 179 & 85.50 & 84.08 & 32.01 \\
\hline & Sakha 104 & 96.83 & 94.33 & 25.89 \\
\hline & SK2034H & 98.17 & 94.41 & 33.94 \\
\hline & SK2003H & 98.50 & 97.28 & 41.35 \\
\hline LSD 0.05 & & 0.958 & 1.487 & 1.958 \\
\hline
\end{tabular}


Table 7. Effect the different sources of growth promoter supplement of rice varieties and their interaction on number of panicles / plant, panicle length, panicle weight and number of filled grains / panicle ${ }^{-1}$ during 2019 and 2020 seasons and combined data

\begin{tabular}{|c|c|c|c|c|c|c|c|c|c|c|c|c|}
\hline \multirow[t]{2}{*}{ Main effect } & \multicolumn{2}{|c|}{$\begin{array}{c}\text { Number of } \\
\text { panicles per } \\
\text { plant }^{-1}\end{array}$} & \multicolumn{4}{|c|}{$\begin{array}{l}\text { Panicle length } \\
(\mathrm{cm})\end{array}$} & \multicolumn{2}{|c|}{$\begin{array}{c}\text { Panicle weight } \\
\text { (g) }\end{array}$} & \multicolumn{4}{|c|}{$\begin{array}{l}\text { No. of filled grains } \\
\text { per panicle }^{-1}\end{array}$} \\
\hline & 2019 & 2020 & Comb. & 2019 & 2020 & Comb. & 2019 & 2020 & Comb. & 2019 & 2020 & Comb. \\
\hline \multicolumn{13}{|c|}{ Growth Promoter } \\
\hline Control & 11.93 & 12.44 & 12.18 & 19.70 & 19.53 & 19.62 & 3.07 & 3.13 & 3.11 & 109.48 & 111.23 & 110.35 \\
\hline Viusid agro & 16.76 & 16.38 & 16.57 & 20.91 & 20.41 & 20.66 & 3.67 & 3.65 & 3.66 & 129.52 & 125.36 & 127.44 \\
\hline Alfarid 1 & 16.36 & 15.91 & 16.13 & 21.30 & 20.58 & 20.94 & 3.78 & 3.64 & 3.71 & 128.87 & 126.17 & 127.52 \\
\hline Humic plus & 13.57 & 14.37 & 13.97 & 20.40 & 20.42 & 20.42 & 3.30 & 3.37 & 3.33 & 119.55 & 119.69 & 119.62 \\
\hline LSD 0.05 & 0.351 & 0.588 & 0.290 & 0.338 & 0.382 & 0.275 & 0.071 & 0.113 & 0.073 & 1.752 & 1.730 & 1.704 \\
\hline \multicolumn{13}{|l|}{ Rice Varieties (V) } \\
\hline GZ10101 & 14.70 & 14.92 & 14.81 & 21.05 & 20.60 & 20.83 & 3.08 & 2.96 & 3.03 & 100.33 & 99.50 & 99.92 \\
\hline GZ10154 & 14.83 & 15.34 & 15.09 & 21.20 & 21.18 & 21.19 & 3.21 & 3.07 & 3.14 & 104.38 & 98.46 & 101.42 \\
\hline GZ10365 & 14.54 & 14.65 & 14.60 & 19.95 & 20.47 & 20.21 & 3.14 & 3.23 & 3.19 & 103.79 & 101.40 & 102.60 \\
\hline MJ5460 & 10.94 & 10.70 & 10.82 & 16.42 & 16.06 & 16.24 & 4.43 & 4.53 & 4.48 & 143.72 & 140.90 & 142.30 \\
\hline Giza 178 & 13.98 & 14.24 & 14.11 & 21.37 & 20.03 & 20.70 & 3.25 & 3.30 & 3.28 & 136.92 & 133.66 & 135.29 \\
\hline Giza 179 & 15.72 & 16.09 & 15.90 & 20.16 & 19.06 & 19.61 & 3.20 & 3.11 & 3.16 & 111.97 & 110.41 & 111.19 \\
\hline Sakha 104 & 13.69 & 14.11 & 13.90 & 19.87 & 20.67 & 20.27 & 3.06 & 3.08 & 3.07 & 103.00 & 107.73 & 105.37 \\
\hline SK2034H & 16.72 & 16.32 & 16.52 & 21.96 & 21.38 & 21.67 & 3.38 & 3.44 & 3.41 & 137.87 & 137.30 & 137.59 \\
\hline SK2003H & 16.75 & 16.62 & 16.69 & 23.25 & 22.70 & 22.98 & 4.36 & 4.29 & 4.33 & 154.73 & 156.15 & 155.44 \\
\hline LSD 0.05 & 0.843 & 0.788 & 0.617 & 0.460 & 0.491 & 0.360 & 0.086 & 0.123 & 0.076 & 1.869 & 2.152 & 1.540 \\
\hline \multicolumn{13}{|l|}{ Interaction } \\
\hline $\mathrm{G} \times \mathrm{V}$ & $* *$ & $* *$ & $* *$ & $* *$ & $* *$ & $* *$ & $* *$ & $* *$ & $* *$ & $* *$ & $* *$ & $* *$ \\
\hline
\end{tabular}


Table 8. The effect of the interaction between growth promoter supplement and rice varieties on number of panicles plant ${ }^{-1}$, panicle length $(\mathrm{cm})$, panicle weight $\left(\mathrm{cm}^{2}\right)$ and number of filled grains panicle ${ }^{-1}$ for combined data

\begin{tabular}{|c|c|c|c|c|c|}
\hline \multirow[t]{2}{*}{$\begin{array}{l}\text { Growth Promoter } \\
\text { Supplement }(\mathbf{G})\end{array}$} & \multirow[t]{2}{*}{$\begin{array}{c}\text { Rice Varieties } \\
\text { (V) }\end{array}$} & \multirow{2}{*}{$\begin{array}{c}\begin{array}{c}\text { No. of panicles } \\
\text { per }^{-1 a n t^{-1}}\end{array} \\
\text { Comb. } \\
\end{array}$} & \multirow{2}{*}{$\begin{array}{c}\begin{array}{c}\text { Panicle } \\
\text { length }(\mathrm{cm})\end{array} \\
\text { Comb. } \\
\end{array}$} & \multirow{2}{*}{$\begin{array}{c}\text { Panicle weight } \\
\text { (g) }\end{array}$} & \multirow{2}{*}{$\begin{array}{c}\begin{array}{c}\text { No. of filled } \\
\text { grains per } \\
\text { panicle }^{-1}\end{array} \\
\text { Comb. } \\
\end{array}$} \\
\hline & & & & & \\
\hline \multirow{9}{*}{ Control } & GZ10101 & 11.00 & 20.39 & 2.71 & 91.00 \\
\hline & GZ10154 & 12.02 & 20.72 & 3.05 & 92.25 \\
\hline & GZ10365 & 11.56 & 19.48 & 3.02 & 99.90 \\
\hline & MJ5460 & 9.23 & 15.28 & 3.88 & 131.00 \\
\hline & Giza 178 & 12.20 & 20.45 & 2.87 & 124.33 \\
\hline & Giza 179 & 13.72 & 19.49 & 2.85 & 100.00 \\
\hline & Sakha 104 & 11.68 & 18.74 & 2.78 & 94.50 \\
\hline & SK2034H & 13.25 & 20.58 & 3.06 & 118.17 \\
\hline & SK2003H & 15.03 & 21.39 & 3.72 & 142.05 \\
\hline \multirow{9}{*}{ Viusid agro } & GZ10101 & 16.71 & 20.53 & 3.18 & 103.17 \\
\hline & GZ10154 & 17.31 & 21.74 & 3.22 & 103.31 \\
\hline & GZ10365 & 16.40 & 20.73 & 3.14 & 103.67 \\
\hline & MJ5460 & 12.23 & 16.94 & 4.90 & 148.33 \\
\hline & Giza 178 & 16.06 & 20.55 & 3.55 & 145.16 \\
\hline & Giza 179 & 18.31 & 20.21 & 3.55 & 120.76 \\
\hline & Sakha 104 & 14.13 & 20.07 & 3.20 & 114.10 \\
\hline & SK2034H & 19.68 & 22.19 & 3.60 & 146.17 \\
\hline & SK2003H & 18.29 & 23.00 & 4.63 & 162.29 \\
\hline \multirow{9}{*}{ Alfarid 1} & GZ10101 & 16.58 & 21.69 & 3.10 & 104.00 \\
\hline & GZ10154 & 16.78 & 20.80 & 3.36 & 108.33 \\
\hline & GZ10365 & 16.56 & 20.83 & 3.45 & 104.75 \\
\hline & MJ5460 & 10.69 & 17.00 & 4.99 & 148.21 \\
\hline & Giza 178 & 15.43 & 20.98 & 3.45 & 142.50 \\
\hline & Giza 179 & 17.09 & 19.13 & 3.10 & 116.50 \\
\hline & Sakha 104 & 16.33 & 21.50 & 3.42 & 110.02 \\
\hline & SK2034H & 18.28 & 22.41 & 3.72 & 145.20 \\
\hline & SK2003H & 17.47 & 24.13 & 4.82 & 168.20 \\
\hline \multirow{9}{*}{ Humic plus } & GZ10101 & 14.97 & 20.68 & 3.10 & 101.50 \\
\hline & GZ10154 & 14.23 & 21.50 & 2.94 & 101.79 \\
\hline & GZ10365 & 13.87 & 19.78 & 3.14 & 102.07 \\
\hline & MJ5460 & 11.14 & 15.74 & 4.15 & 141.69 \\
\hline & Giza 178 & 12.73 & 20.82 & 3.25 & 129.17 \\
\hline & Giza 179 & 14.49 & 19.60 & 3.12 & 107.50 \\
\hline & Sakha 104 & 13.47 & 20.78 & 2.87 & 102.83 \\
\hline & SK2034H & 14.87 & 21.50 & 3.27 & 140.83 \\
\hline & SK2003H & 15.97 & 23.37 & 4.13 & 149.22 \\
\hline LSD 0.05 & & 1.235 & 0.720 & 0.152 & 3.079 \\
\hline
\end{tabular}


Results in Table 9 revealed the effect of different sources of growth promoter supplement on seed set (\%), 1000 grain weight $(\mathrm{g})$, grain yield (t/fed.) and harvest index (\%) of rice varieties as well as, their interaction. Results showed that, seed set (\%), 1000 grain weight $(\mathrm{g})$, grain yield (t/fed.) and harvest index (\%) were highly affected by growth promoter supplement during two seasons and combined data. The spraying growth promoter supplement such as viusid agro and alfarid 1 increased seed set\%, 1000 - grain weight, grain yield (t/fed.) and harvest index \% by application these growth promoter supplement during two seasons, the highest values for the these traits recorded with treatment viusid agro and alfarid 1 compared to control treatment during two seasons. Also, the results in the Table 9 clarified that there were a significant differences among the rice varieties for the same characters. The varieties GZ10101, GZ10154, MJ5460, SK2034H and SK2003H recorded the highest values for these traits during two seasons. While, the hybrid SK2003H and Giza 178 recoded the un desirable values for seed set $\%$ and 1000 grain weight traits, also, The line GZ10365 and Sakha 104 recorded the lowest values for grain yield ( $t / f e d)$ and harvest index during two seasons. All the interaction between two factors studied had significant effect on these traits indicating the dependent effect of each one this trait in the two seasons. Albion (2000) and Johansson (2008) obtained that, in fertilizers, amino acids form organic connections with minerals (amino acid chelates), which increase the availability of nutrients by plants.

Results in Table 10 revealed the effect of the interaction between growth promoter supplement and rice varieties on yield and its component traits. The results showed that, seed set\%, 1000 grain weight, grain yield (t/fed) and harvest index were highly affected by growth promoter supplement and rice varieties during two seasons (combined data), the desirable value for the seed set\% were $(96.52 \%)$ by application viusid agro and alfarid 1 of the rice variety Giza 179 during two seasons, while, the undesirable value for seed set $\%$ recorded $(86.90 \%)$ of the MJ5460 were without spraying during two seasons.

Also, 1000 grain weight was highly affected by growth promoter supplement and rice varieties during two seasons, the desirable value for the 1000 grain weight was $(30.00 \mathrm{~g})$ with the application viusid agro of the line MJ 5460 during two seasons, while, the un desirable value for 1000 grain weight recorded (18.83 g) with control treatment of rice variety Giza 178 during two seasons.

Concerning, grain yield (t/fed.) was highly affected by growth promoter supplement and rice varieties during two seasons, the desirable value for grain yield (t/fed.) were ( $4.31 \mathrm{t} / \mathrm{fed})$ by spraying viusid agro of the hybrid SK2034H and SK2003H during two seasons, while, the un desirable value for grain yield ( $t / f e d$. recorded $(2.75 \mathrm{t} / \mathrm{fed})$ without application for the rice variety GZ10365 and Sakha 104 during two seasons.

Also, results showed that, harvest index was highly affected by growth promoter supplement and rice varieties during two seasons. The desirable values of harvest index recorded $(50.12 \%)$ with spraying viusid agro of the hybrid SK2003H during two seasons, but, the lowest values for harvest index \% were $(39.03 \%)$ recorded of the rice variety Sakha 104 and without spraying growth promoter supplement during two seasons.

Results in Table 11 revealed the effect of different sources of growth promoter supplement on technological traits such as hulling (\%), milling (\%), head rice $(\%)$ and amylose content $(\%)$ and rice varieties as well as, their interaction. Results showed that, hulling (\%), milling (\%), head rice $(\%)$ and amylose content $(\%)$ were highly affected by growth promoter supplement during two seasons (combined data). The spraying growth promoter supplement such as viusid agro and alfarid 1 increased hulling (\%), milling (\%), head rice (\%) and amylose content (\%) by application these growth promoter supplement during two seasons. The highest values for these traits recorded with treatment viusid agro compared to control treatment during two seasons. Also, the results in the Table 11 clarified that there were a significant differences among the rice varieties for the same characters. The varieties GZ10101, GZ10154 and Sakha 104 recorded the highest values for these traits during two seasons. While, the rice varieties MJ5460 recoded the undesirable values for milling $\%$, head rice $\%$ and amylose content $\%$ traits. All the interaction between two factors studied had significant effect on these traits indicating the dependent effect of each one this trait in the two seasons. Albion (2000) and Johansson (2008) obtained that, in fertilizers, amino acids form organic connections with minerals (amino acid chelates), which increase the availability of nutrients by plants and increased technological traits. 
Table 9. Effect of different sources growth promoter supplement of rice varieties and their interaction on seed set (\%), 1000 grain weight (g), grain yield per plant $(\mathrm{g})$ and harvest index $(\%)$ during 2019 and 2020 seasons and combined data

\begin{tabular}{|c|c|c|c|c|c|c|c|c|c|c|c|c|}
\hline \multirow[t]{2}{*}{ Main effect } & \multicolumn{2}{|c|}{ Seed set $(\%)$} & \multicolumn{4}{|c|}{$\begin{array}{l}1000 \text { grain } \\
\text { weight (g) }\end{array}$} & \multicolumn{2}{|c|}{ Grain yield (t/fed) } & \multicolumn{4}{|c|}{ Harvest index (\%) } \\
\hline & 2019 & 2020 & Comb. & 2019 & 2020 & Comb. & 2019 & 2020 & Comb. & 2019 & 2020 & Comb. \\
\hline \multicolumn{13}{|l|}{ Growth Promoter } \\
\hline \multicolumn{13}{|l|}{ Supplement (G) } \\
\hline Control & 89.92 & 89.73 & 89.83 & 24.31 & 24.13 & 24.22 & 3.05 & 3.02 & 3.04 & 41.39 & 41.41 & 41.40 \\
\hline VIiusid agro & 94.46 & 93.93 & 94.20 & 26.24 & 26.65 & 26.45 & 3.98 & 3.92 & 3.95 & 47.81 & 47.76 & 47.79 \\
\hline Alfarid 1 & 93.10 & 93.27 & 93.19 & 25.85 & 26.11 & 25.98 & 3.88 & 3.90 & 3.89 & 46.04 & 46.20 & 46.12 \\
\hline Humic plus & 92.09 & 91.31 & 91.70 & 25.08 & 25.29 & 25.19 & 3.44 & 3.56 & 3.50 & 43.24 & 43.70 & 43.47 \\
\hline LSD 0.05 & 0.724 & 0.583 & 0.507 & 0.423 & 0.325 & 0.201 & 0.050 & 0.055 & 0.035 & 0.411 & 0.782 & 0.590 \\
\hline \multicolumn{13}{|l|}{ Rice Varieties (V) } \\
\hline GZ10101 & 94.25 & 93.69 & 93.97 & 26.36 & 26.62 & 26.49 & 3.39 & 3.34 & 3.37 & 45.18 & 44.49 & 44.84 \\
\hline GZ10154 & 94.56 & 93.35 & 93.95 & 27.46 & 27.69 & 27.57 & 3.39 & 3.45 & 3.42 & 45.31 & 45.36 & 45.34 \\
\hline GZ10365 & 94.11 & 93.33 & 93.72 & 26.18 & 26.90 & 26.54 & 3.35 & 3.31 & 3.34 & 43.98 & 44.12 & 44.06 \\
\hline MJ5460 & 89.91 & 89.52 & 89.71 & 28.69 & 28.03 & 28.36 & 3.65 & 3.75 & 3.70 & 45.94 & 45.56 & 45.75 \\
\hline Giza 178 & 92.41 & 92.20 & 92.31 & 19.40 & 20.49 & 19.95 & 3.58 & 3.56 & 3.57 & 43.39 & 43.73 & 43.56 \\
\hline Giza 179 & 92.79 & 93.79 & 93.29 & 26.05 & 26.45 & 26.25 & 3.81 & 3.79 & 3.80 & 44.96 & 45.75 & 45.36 \\
\hline Sakha 104 & 92.82 & 92.20 & 92.52 & 27.26 & 25.88 & 26.57 & 3.37 & 3.44 & 3.40 & 40.93 & 42.48 & 41.71 \\
\hline SK2034H & 91.21 & 91.10 & 91.15 & 22.69 & 23.19 & 22.94 & 3.85 & 3.88 & 3.87 & 45.68 & 45.27 & 45.47 \\
\hline SK2003H & 89.47 & 89.38 & 89.43 & 24.28 & 24.66 & 24.47 & 3.91 & 3.87 & 3.89 & 46.22 & 46.12 & 46.17 \\
\hline LSD 0.05 & 0.906 & 0.734 & 0.550 & 0.327 & 0.426 & 0.275 & 0.073 & 0.087 & 0.061 & 0.701 & 0.714 & 0.526 \\
\hline \multicolumn{13}{|l|}{ Interaction } \\
\hline $\mathrm{G} \times \mathrm{V}$ & $* *$ & $* *$ & $* *$ & $* *$ & $* *$ & $* *$ & $* *$ & $* *$ & $* *$ & $* *$ & $* *$ & $* *$ \\
\hline
\end{tabular}


Table 10. The effect of the interaction between growth promoter supplement and rice varieties on seed set (\%), 1000 grain weight $(\mathrm{g})$, grain yield $(\mathrm{t} / \mathrm{fed})$ and harvest index $(\%)$ for combined data

\begin{tabular}{|c|c|c|c|c|c|}
\hline \multirow{2}{*}{$\begin{array}{c}\text { Growth Promoter } \\
\text { Supplement }(G)\end{array}$} & \multirow[t]{2}{*}{ Rice Varieties (V) } & \multirow{2}{*}{$\begin{array}{c}\text { Seed set (\%) } \\
\text { Comb. }\end{array}$} & \multirow{2}{*}{ 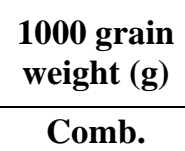 } & \multirow{2}{*}{$\begin{array}{c}\begin{array}{c}\text { Grain yield } \\
\text { (t/fed.) }\end{array} \\
\text { Comb. }\end{array}$} & \multirow{2}{*}{$\begin{array}{c}\begin{array}{c}\text { Harvest } \\
\text { index }(\%)\end{array} \\
\text { Comb. }\end{array}$} \\
\hline & & & & & \\
\hline \multirow{9}{*}{ Control } & GZ10101 & 91.31 & 24.76 & 2.93 & 41.16 \\
\hline & GZ10154 & 91.89 & 26.55 & 2.93 & 41.97 \\
\hline & GZ10365 & 90.77 & 24.83 & 2.75 & 40.30 \\
\hline & MJ5460 & 86.90 & 27.02 & 2.97 & 42.32 \\
\hline & Giza 178 & 89.60 & 18.83 & 3.03 & 40.65 \\
\hline & Giza 179 & 90.64 & 25.77 & 3.33 & 42.34 \\
\hline & Sakha 104 & 90.62 & 25.57 & 2.75 & 39.03 \\
\hline & SK2034H & 89.68 & 21.43 & 3.35 & 42.05 \\
\hline & SK2003H & 87.05 & 23.25 & 3.32 & 42.78 \\
\hline \multirow{9}{*}{ Viusid agro } & GZ10101 & 95.80 & 28.12 & 3.38 & 47.33 \\
\hline & GZ10154 & 95.29 & 27.72 & 3.73 & 48.67 \\
\hline & GZ10365 & 96.09 & 27.83 & 3.73 & 47.33 \\
\hline & MJ5460 & 92.54 & 30.00 & 4.21 & 48.57 \\
\hline & Giza 178 & 95.55 & 20.21 & 3.92 & 46.01 \\
\hline & Giza 179 & 96.52 & 26.75 & 4.15 & 48.04 \\
\hline & Sakha 104 & 92.81 & 27.22 & 3.80 & 45.31 \\
\hline & SK2034H & 92.21 & 24.12 & 4.31 & 48.71 \\
\hline & SK2003H & 90.99 & 26.03 & 4.31 & 50.12 \\
\hline \multirow{9}{*}{ Alfarid 1} & GZ10101 & 93.57 & 27.09 & 3.83 & 47.29 \\
\hline & GZ10154 & 94.10 & 28.20 & 3.66 & 47.26 \\
\hline & GZ10365 & 96.10 & 27.28 & 3.57 & 46.18 \\
\hline & MJ5460 & 90.95 & 28.77 & 4.01 & 46.55 \\
\hline & Giza 178 & 93.43 & 21.13 & 3.81 & 45.07 \\
\hline & Giza 179 & 93.31 & 26.61 & 4.09 & 46.70 \\
\hline & Sakha 104 & 94.52 & 27.13 & 3.77 & 44.53 \\
\hline & SK2034H & 92.29 & 23.67 & 4.07 & 45.15 \\
\hline & SK2003H & 90.39 & 23.95 & 4.15 & 46.38 \\
\hline \multirow{9}{*}{ Humic plus } & GZ10101 & 95.22 & 25.97 & 3.32 & 43.57 \\
\hline & GZ10154 & 94.55 & 27.82 & 3.36 & 43.45 \\
\hline & GZ10365 & 91.93 & 26.22 & 3.28 & 42.40 \\
\hline & MJ5460 & 88.48 & 27.67 & 3.60 & 45.56 \\
\hline & Giza 178 & 90.64 & 19.60 & 3.52 & 42.53 \\
\hline & Giza 179 & 92.69 & 25.87 & 3.63 & 44.36 \\
\hline & Sakha 104 & 92.11 & 26.37 & 3.27 & 37.97 \\
\hline & SK2034H & 90.43 & 22.54 & 3.73 & 46.00 \\
\hline & SK2003H & 89.27 & 24.63 & 3.78 & 45.38 \\
\hline LSD 0.05 & & 1.099 & 0.552 & 0.122 & 1.053 \\
\hline
\end{tabular}


Table 11. Effect of different sources growth promoter supplement of rice varieties and their interaction on hulling $(\%)$, milling $(\%)$, head rice $(\%)$ and amylose content $(\%)$ for combined data

\begin{tabular}{lcccc}
\hline \multicolumn{1}{c}{ Main effect } & Hulling (\%) & Milling $\mathbf{( \% )}$ & Head rice (\%) & Amylose (\%) \\
\hline Growth Promoter & & & & \\
Supplement (G) & & & & \\
Control & 79.85 & 67.26 & 58.30 & 18.99 \\
VIiusid agro & 82.24 & 70.44 & 61.87 & 17.41 \\
Alfarid 1 & 80.44 & 69.67 & 61.11 & 18.05 \\
Humic plus & 80.04 & 68.79 & 60.37 & 18.36 \\
LSD 0.05 & $\mathbf{0 . 4 7 7}$ & $\mathbf{0 . 2 9 9}$ & $\mathbf{0 . 4 5 6}$ & $\mathbf{0 . 2 9 6}$ \\
\hline Rice Varieties (V) & & & & \\
GZ10101 & 81.58 & 71.44 & 64.58 & 17.57 \\
GZ10154 & 80.75 & 70.91 & 63.13 & 17.68 \\
GZ10365 & 80.74 & 71.25 & 63.33 & 18.30 \\
MJ5460 & 80.17 & 69.50 & 59.91 & 19.51 \\
Giza 178 & 81.13 & 66.58 & 59.83 & 18.49 \\
Giza 179 & 79.92 & 67.08 & 50.25 & 17.55 \\
Sakha 104 & 61.27 & 69.66 & 62.75 & 18.03 \\
SK2034H & 80.33 & 68.00 & 60.16 & 18.57 \\
SK2003H & 79.91 & $\mathbf{0 . 5 3 6}$ & 59.75 & $\mathbf{0 . 3 6 7}$ \\
LSD 0.05 & $\mathbf{0 . 5 2 0}$ & $* *$ & $\mathbf{0 . 6 7 6}$ & $*$ \\
\hline Interaction & $* *$ & $* *$ & \\
G X V & & & & \\
\hline
\end{tabular}

Results in Table 12 revealed the effect of the interaction between growth promoter supplement and rice varieties on technological traits. The results showed that, hulling $\%$, milling $\%$, head rice $\%$ and amylose content $(\%)$ were highly affected by growth promoter supplement and rice varieties during two seasons (combined data). the desirable values for the hulling\% was $(83.33 \%)$ by application viusid agro of rice varieties GZ10101, GZ10365, Giza 178 and Sakha 104, while, the undesirable values for hulling\% recorded for the rice variety Giza 179 was (79.33\%) without spraying growth promoter supplement.

With respect to, milling\% was highly affected by growth promoter supplement and rice varieties during two seasons, the desirable value for the milling\% was $(73.00 \%)$ with the application viusid agro of the promising lines GZ10101, 10154 and GZ10365, while, the un desirable value for milling\% recorded $(64.66 \%)$ with control treatment of rice variety Giza 178 and the promising hybrid SK2003H.

Concerning to, head rice\% was highly affected by growth promoter supplement and rice varieties, the desirable value for head rice\% was $(68.00 \%)$ by spraying viusid agro of the promising line GZ10101, while, the un desirable value for head rice\% recorded $(44.70 \%)$ without application of the rice variety Giza 179.

Also, a result showed that, amylose\% was highly affected by growth promoter supplement and rice varieties. The desirable values of amylose $\%$ recorded $(17.00 \%)$ with spraying viusid agro for the rice varieties GZ10154 and Giza 179, but, the highest value for amylose \% was (20.70\%) recorded of the promising line GZ5460 and without spraying growth promoter supplement.

\section{Phenotypic Correlation Coefficient:}

There are significant positive correlation coefficients among the studied traits under water deficit (irrigation every 8 days) as shown in Table 13 . Phenotypic correlation result indicated that yield (t/fed.) correlated positively and significantly with flag leaf area, no. of panicles per plant, panicle length, panicle weight, number of filled grains per panicle, seed set $\%$, harvest index\% and hulling \%, moreover highly significant and positive correlated was found between milling\% and head rice\%, these results were confirmed with Idris et al (2012) observed positive phenotypic and genotypic correlation coefficient between grain yield and number of filled grain per panicle, harvest index $\%$, panicle length and number of grains per panicle, also, Ullah et al (2011) detected that grain yield was positively and significantly associated with panicle length and grains per panicle. Hairmansis et al (2010) also recorded a positive and significant association of grain yield with filled grains per panicle, grains per panicle and seed setting\%. On the other side, highly significant and negative correlation was found between head rice $\%$ and amylose content $\%$, indicate to there 
were closed relationship between highest value for head rice with lowest value for amylose content $\%$, moreover, could be used the head rice as indicator to the lower amylose content especially the japonica type ha head rice with low amylose content $\%$. These results may be helpful the breeder to understanding the effect of growth promoter supplement on yield of some rice varieties under water deficit (irrigation every 8 days).

The response of studied traits to growth promoter supplement:

Table 12. The effect of the interaction between growth promoter supplement and rice varieties on hulling\%, milling\%, head rice\% and amylose content \% for combined data two seasons

\begin{tabular}{|c|c|c|c|c|c|}
\hline Growth Promoter & Rice Varieties & $\begin{array}{c}\text { Hulling } \\
(\%)\end{array}$ & $\begin{array}{c}\text { Milling } \\
(\%)\end{array}$ & $\begin{array}{c}\text { Head rice } \\
(\%)\end{array}$ & $\begin{array}{c}\text { Amylose } \\
(\%)\end{array}$ \\
\hline \multirow{9}{*}{ Control } & GZ10101 & 80.33 & 70.00 & 60.33 & 19.15 \\
\hline & GZ10154 & 80.00 & 69.00 & 61.67 & 18.54 \\
\hline & GZ10365 & 79.66 & 69.00 & 62.00 & 19.10 \\
\hline & MJ5460 & 79.67 & 68.00 & 58.33 & 20.70 \\
\hline & Giza 178 & 80.33 & 64.66 & 59.00 & 18.68 \\
\hline & Giza 179 & 79.33 & 66.33 & 44.70 & 18.63 \\
\hline & Sakha 104 & 80.00 & 66.66 & 61.66 & 18.51 \\
\hline & SK2034H & 79.66 & 67.00 & 58.66 & 18.35 \\
\hline & SK2003H & 79.67 & 64.66 & 58.33 & 19.28 \\
\hline \multirow{9}{*}{ Viusid agro } & GZ10101 & 83.30 & 73.00 & 68.00 & 17.66 \\
\hline & GZ10154 & 83.00 & 73.00 & 62.53 & 17.00 \\
\hline & GZ10365 & 83.30 & 73.00 & 63.67 & 18.60 \\
\hline & MJ5460 & 81.00 & 70.00 & 60.00 & 17.59 \\
\hline & Giza 178 & 83.30 & 68.00 & 60.67 & 19.42 \\
\hline & Giza 179 & 81.00 & 68.00 & 54.66 & 17.00 \\
\hline & Sakha 104 & 83.30 & 72.00 & 64.66 & 17.44 \\
\hline & SK2034H & 82.00 & 69.00 & 61.67 & 17.60 \\
\hline & SK2003H & 80.00 & 68.00 & 61.00 & 17.35 \\
\hline \multirow{9}{*}{ Alfarid 1} & GZ10101 & 81.66 & 72.03 & 65.33 & 18.32 \\
\hline & GZ10154 & 80.00 & 72.00 & 64.66 & 17.45 \\
\hline & GZ10365 & 80.00 & 72.00 & 63.67 & 17.30 \\
\hline & MJ5460 & 80.00 & 70.00 & 61.00 & 19.59 \\
\hline & Giza 178 & 80.87 & 66.67 & 59.66 & 17.53 \\
\hline & Giza 179 & 80.33 & 67.00 & 53.33 & 17.34 \\
\hline & Sakha 104 & 81.11 & 71.00 & 62.00 & 18.26 \\
\hline & SK2034H & 80.00 & 68.33 & 60.33 & 17.95 \\
\hline & SK2003H & 80.00 & 68.00 & 60.00 & 18.70 \\
\hline \multirow{9}{*}{ Humic plus } & GZ10101 & 81.00 & 70.75 & 64.66 & 18.14 \\
\hline & GZ10154 & 80.00 & 69.67 & 63.67 & 17.73 \\
\hline & GZ10365 & 80.00 & 71.00 & 64.00 & 18.20 \\
\hline & MJ5460 & 80.00 & 70.00 & 60.33 & 20.17 \\
\hline & Giza 178 & 80.00 & 67.00 & 60.00 & 18.32 \\
\hline & Giza 179 & 79.00 & 67.00 & 48.33 & 17.27 \\
\hline & Sakha 104 & 80.67 & 69.00 & 62.67 & 18.25 \\
\hline & SK2034H & 79.66 & 67.67 & 60.00 & 18.23 \\
\hline & SK2003H & 80.00 & 67.00 & 59.67 & 18.95 \\
\hline LSD 0.05 & & 1.041 & 1.072 & 1.352 & 0.734 \\
\hline
\end{tabular}

The effect of different sources of growth promoter supplement on the productivity of rice varieties for some studied traits is presented in Fig. (1 and 2). Grain yield under the viusid agro was significantly exceeded control by $23.09 \%$. Yield increasing due to viusid agro and alfarid 1 were accompanied by significant increasing in number of panicles per plant (26.44 and $24.46 \%), 1000$ grain weight (8.40 and 6.77\%) compared with control treatment as shown in Table 14. 
Table 13.Phenotypic correlation coefficients among growth, yield and its component traits of some rice genotype during two season (combined data)

\begin{tabular}{|c|c|c|c|c|c|c|c|c|c|c|c|c|c|c|}
\hline Traits & DTH & P.H & FLA & NOP & PL & PW & $\mathrm{NOF}$ & SS & TGW & GY & $\mathrm{HI} \%$ & Hulling\% & Milling\% & $\mathrm{HR}$ \\
\hline $\mathrm{PH}$ & $0.500^{* * *}$ & & & & & & & & & & & & & \\
\hline FLA & $0.242^{*}$ & $0.265^{* *}$ & & & & & & & & & & & & \\
\hline NOP & -0.156 & $0.529^{* *}$ & $0.304^{* *}$ & & & & & & & & & & & \\
\hline PL & $0.212^{*}$ & $0.665^{* *}$ & 0.110 & $0.681^{* *}$ & & & & & & & & & & \\
\hline PW & $0.358^{* *}$ & 0.080 & $0.749^{* *}$ & 0.079 & -0.092 & & & & & & & & & \\
\hline $\mathrm{NOF}$ & $0.574^{* *}$ & $0.326^{* *}$ & $0.806^{* *}$ & $0.216^{*}$ & 0.123 & $0.814^{* *}$ & & & & & & & & \\
\hline SS & $-0.513^{* *}$ & 0.098 & $-0.235^{*}$ & $0.511^{* *}$ & 0.237 & $-0.231^{*}$ & $-0.362^{* *}$ & & & & & & & \\
\hline TGW & $-0.469^{* *}$ & $-0.359^{* *}$ & -0.042 & 0.001 & $-0.328^{* *}$ & $0.200^{*}$ & $-0.296^{* * *}$ & $0.313^{* *}$ & & & & & & \\
\hline GY & 0.035 & $0.390^{* *}$ & $0.698^{* *}$ & $0.655^{* *}$ & $0.272^{* *}$ & $0.606^{* *}$ & $0.637^{* *}$ & $0.295^{* *}$ & 0.120 & & & & & \\
\hline $\mathrm{HI}$ & $-0.193^{*}$ & 0.116 & $0.542^{* *}$ & $0.621^{* *}$ & 0.175 & $0.529^{* *}$ & $0.438^{* *}$ & $0.403^{* *}$ & $0.326^{* * *}$ & $0.824^{* *}$ & & & & \\
\hline $\mathrm{HU}$ & -0.113 & 0.156 & -0.126 & $0.338^{* *}$ & 0.120 & -0.085 & -0.082 & $0.548^{* *}$ & 0.134 & $0.251^{* *}$ & $0.380^{* *}$ & & & \\
\hline MI & $-0.332^{* *}$ & -0.181 & $-0.276^{* *}$ & 0.186 & -0.016 & -0.038 & $-0.370^{* *}$ & $0.567^{* * *}$ & $0.650^{* * *}$ & 0.116 & $0.376^{* *}$ & $0.518^{* *}$ & & \\
\hline $\mathrm{HR} \%$ & $0.205^{*}$ & 0.133 & $-0.275^{* *}$ & 0.091 & 0.183 & 0.012 & -0.104 & $0.276^{* *}$ & $0.193^{*}$ & -0.063 & 0.112 & $0.428^{* *}$ & $0.623^{* *}$ & \\
\hline $\mathrm{AC}$ & $0.400^{* * *}$ & $-0.218^{*}$ & 0.022 & $-0.522^{* *}$ & $-0.340^{* *}$ & 0.166 & $0.204^{*}$ & $-0.592^{* *}$ & $-0.200^{*}$ & $-0.290^{* *}$ & $-0.398^{* *}$ & $-0.311^{* *}$ & $-0.308^{* *}$ & -0.150 \\
\hline
\end{tabular}

DTH: Days to heading PH: Plant height

NOP: Number of panicles plant ${ }^{-1} \quad$ PL: Panicle length

NOF: Number of filled grains panicle ${ }^{-1} \quad$ SS: Seed set $\%$

GY: Grain yield (t/fed.)

MU: Milling \%

HI: Harvest index $\%$

HR: Head rice \%
FLA: Flag leaf area

PW: Panicle weight

TGW: 1000 grain weight

HU: Hulling \%

AC: Amylose content \%

Table 14 . Relative change of studied traits across all rice varieties under spraying growth promoter supplement (data are combined across (2019 and 2020 seasons)

\begin{tabular}{|c|c|c|c|}
\hline \multirow{2}{*}{ Traits } & \multicolumn{3}{|c|}{ Relative change $\%$} \\
\hline & Viusid Agro/control & Alfarid 1/ control & Humic plus/ control \\
\hline Days to heading (day) & -0.97 & -0.77 & 0.68 \\
\hline Plant height $(\mathrm{cm})$ & 6.20 & 6.34 & 3.56 \\
\hline No. of panicles plant ${ }^{-1}$ & 26.44 & 24.46 & 12.77 \\
\hline Seed set $(\%)$ & 4.56 & 3.61 & 1.86 \\
\hline 1000-grain weight $(\mathrm{g})$ & 8.40 & 6.77 & 3.82 \\
\hline Grain yield/plant (t/fed.) & 23.09 & 21.80 & 13.17 \\
\hline
\end{tabular}




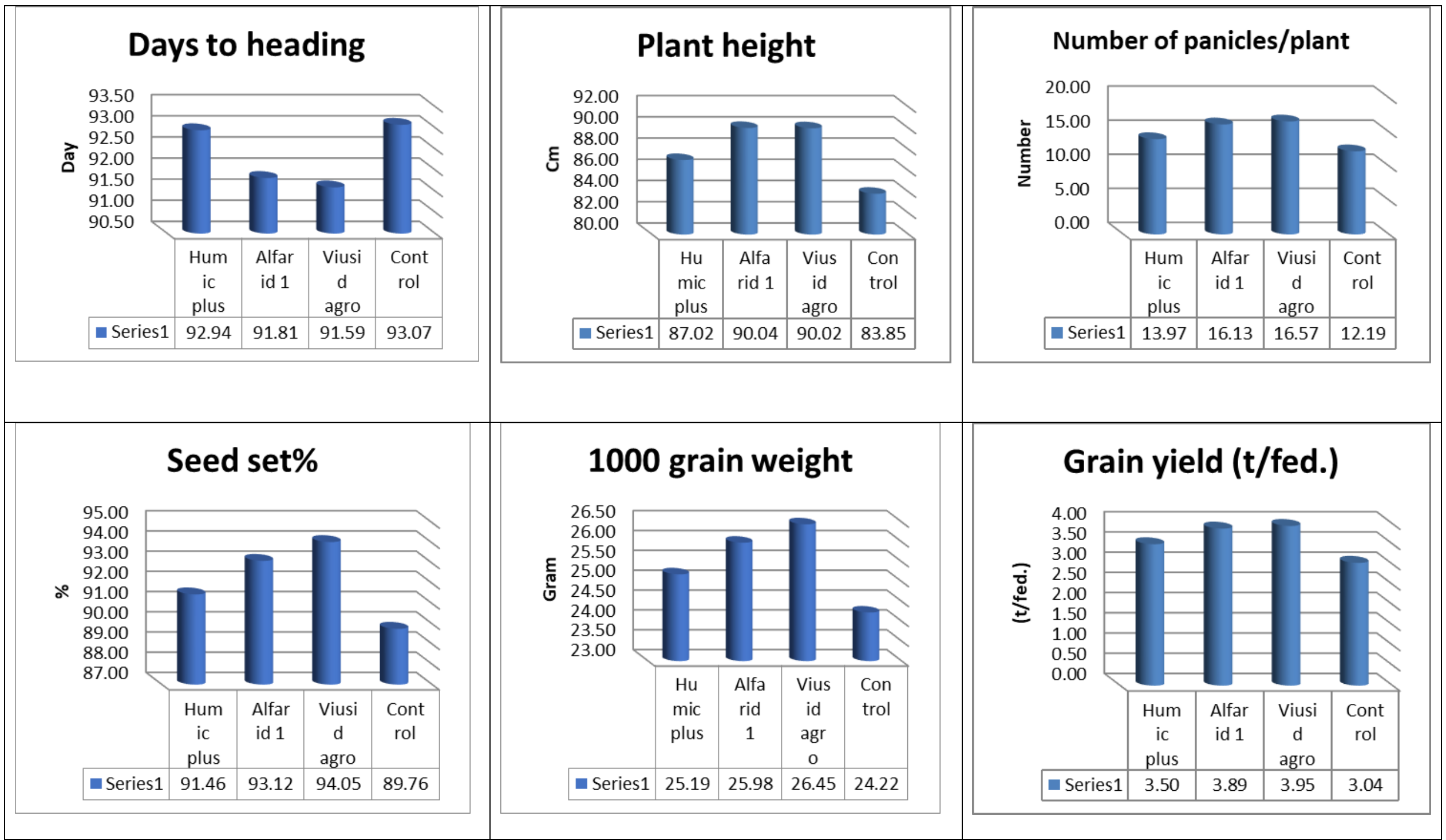

Fig. 1. Effect of spraying growth promoter supplement on some rice varieties for days to heading, plant height and number of panicle per plant, seed set $\%, 1000$ grain weight and grain yield ( $t /$ fed.) under irrigation eight days. 


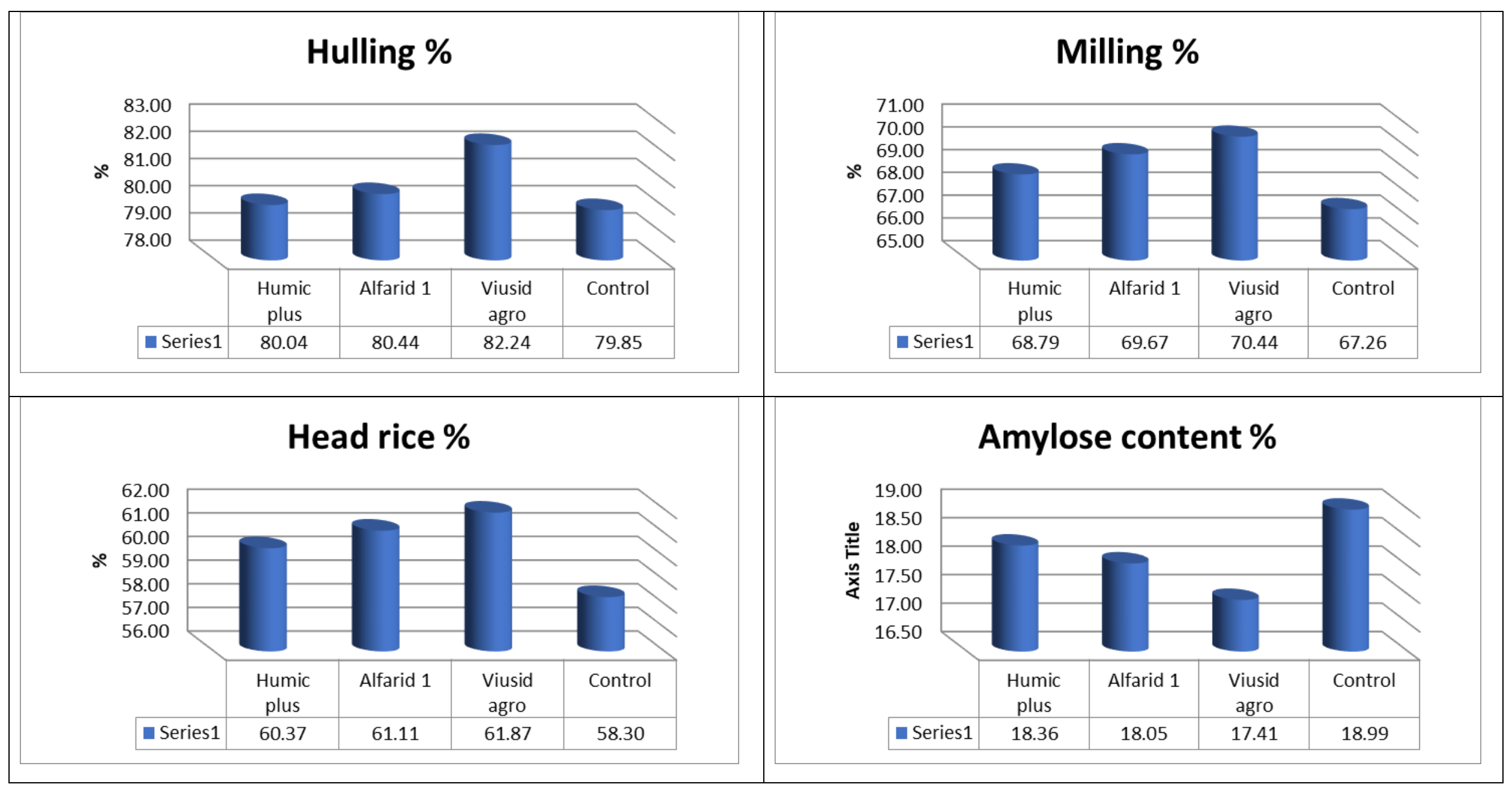

Fig. 2.Effect of spraying growth promoter supplement on some rice varieties for hulling $\%$, milling $\%$, head rice $\%$ and amylose content $\%$ under irrigation eight days. 
Talha, I.A., M.A.Gomma et al.. Enhancement the Productivity of some Rice Varieties by Using Some Growth Promoter Supplement 570

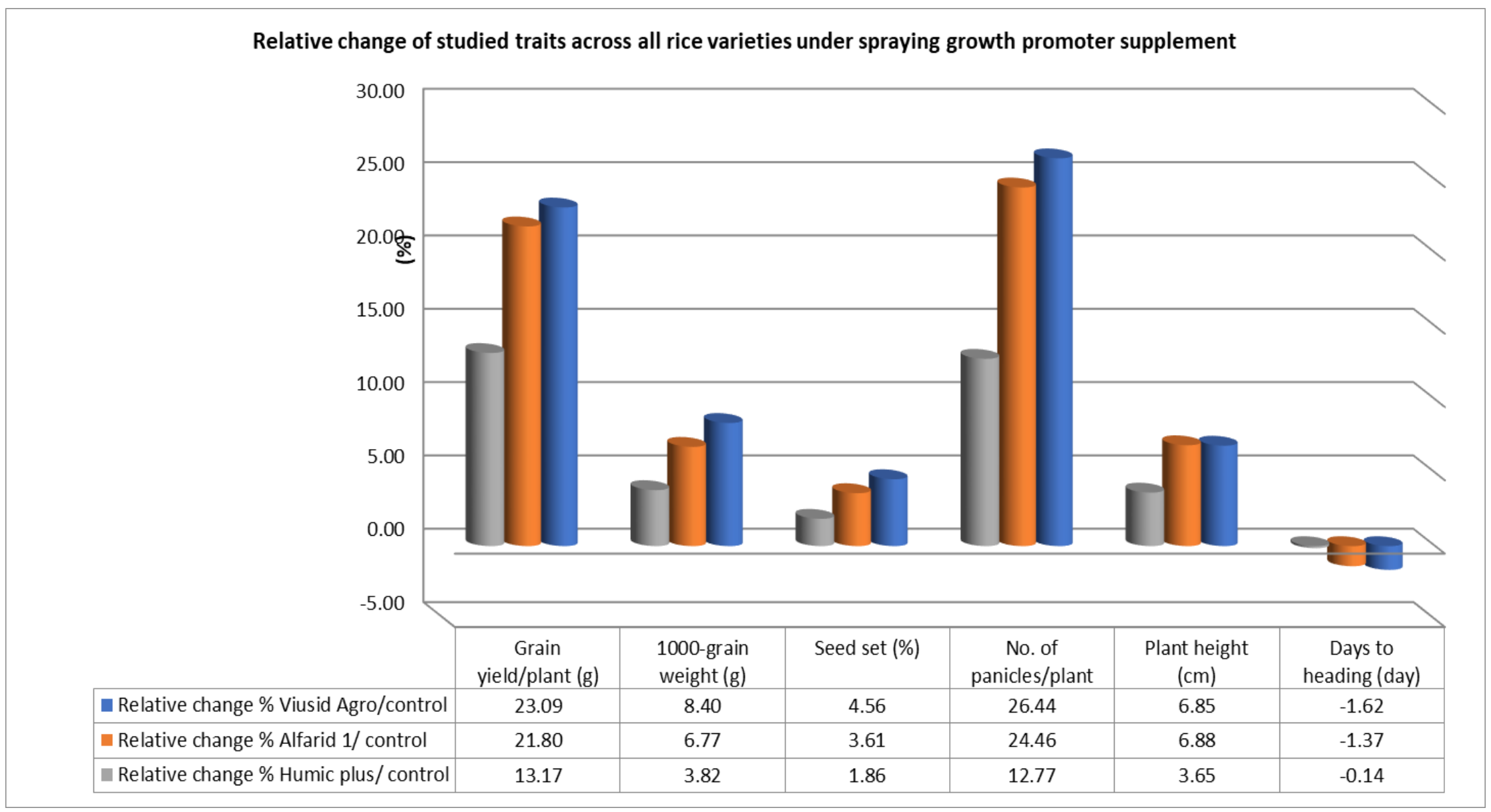

Fig. 3. Relative change of studied traits across all rice varieties under spraying growth promoter supplement (data are combined across 2019 and 2020 seasons). 
Yield reductions due to the control treatment were accompanied by reductions in number of panicles per plant and 1000 grain weight. It was cleared that the viusid agro and alfarid1 had significant effect on increasing grain yield ( $\mathrm{t} / \mathrm{fed}$ ), as well as, most of studied traits as shown in Table 14 and Fig. (3). Therefore, growth promoter supplement (viusid agro and alfarid 1) could be used for increasing rice grain yield in the present investigation.

\section{CONCLUSION}

From the above results, could be concluded that, increasing rice grain yield and related traits were obvious for most studied varieties by applying the growth promoter supplement of viusid agro or alfarid 1 for the hybrids rice SK2034H and SK2003H under the irrigation every eight days, as used for this study.

\section{REFERENCE}

Albion. 2000. What exactly are the Metal sate products? Plant Nutr. Newsl., 1, 1-4.

Amin A.A., A.E. Fatma, M. Gharib, A. El-Awad, M. ElSherbeny and A. Rashad. 2011. Physiological response of onion plants to foliar application of putrescine and glutamine. Scientia Horticulturae.;129:353-360.

Basak A. 2008. Biostimulators - definitions, classification and legislation. In: Gawronska H, editor. Monographs Series: Biostimulators in Modern Agriculture. General Aspects. Warsaw: Wieś Jutra;. pp. 7-17.

Bulgari, R., G. Cocetta, A. Trivellini, P. Vernieri and A. Ferrante. 2015. Biostimulants and crop responses: A review. Biological Agriculture and Horticulture. 31:1- 17.

Colla, G., S. Nardi, M .Cardarelli, A. Ertani, L. Lucini, R. Canaguier and Y. Rouphael. 2015. Protein hydrolysates as biostimulants in horticulture. Sci. Hort. 196:28-38.

Couto C.A., C.P. Peixoto, E.L.Vieira, E.V. Carvalho and V.A.B. Peixoto. 2012. Action by kinetin, indolbutyric acid and acid gibberellic in sunflower emergence under stress by aluminum. Communication Scientiae. 3: 206209.

Du Jardin P. 2012. The science of plant biostimulants-A bibliographic analysis, Ad hoc Study Report..Brussels: European Commission.

Du Jardin P. 2015. Plant biostimulants: Definition, concept, main categories and regulation. Scientia Horticulturae.;196:3-14.

Forde B.G. and P.J. Lea. 2007. Glutamate in plants: Metabolism, regulation, and signaling. Journal of Experimental Botany. 58:2339-2358.

Gomez, K.A. and A.A. Gomez. 1984. Statistical procedures for Agricultural Research. Second Edition. John Wiley \& Sons, New York.
Hairmansis, A., B. Kustianto and S. Supartopo. 2010. Correlation analysis of agronomic characters and grain yield of rice for tidal swamp areas. Indonesian J. Agric. Sci. 11:11-15

Idris, A. E., F. J. Justin, Y. M. I. Dagash and A. L. Abuali. 2012. Genetic Variability and inter relationship between yield and yield component in some Rice Genotypes. Am. J. Exp. Agric. 2(2): 233-239.

IRRI. 2008. Standard Evaluation System for rice 3rd Edition, Int. Rice Testing Programm.

Jan, S. and J.A Parray. 2016. Heavy Metal Uptake in Plants. In Approaches to Heavy Metal Tolerance in Plants; Springer: Singapore. pp. 1-18.

Johansson, A. 2008. Conversations on chelation and mineral nutrition. Aust. J. Grape Wine Res. 583: 53-56.

Kowalczyk, K. and T. Zielony. 2008 . Effect of Aminoplant and Asahi on yield and quality of lettuce grown on rockwool.Conf. of biostimulators in modern agriculture, 7-8 Febuary 2008, Warsaw, Poland.

Lana, A.M.Q. 2009. Application of growth regulators in culture of the bean. Bioscience Journal. 25 (1): 13-20.

Lea, P.J., L. Sodek, M.A.J. Parry, P.R. Shewry and N.G. Halford. 2007. Asparagine in plants. The Annals of Applied Biology.;150:1-26.

Paleckiene, R., A. Sviklas and R. Šlinkšiene. 2007. Physicochemical properties of a microelement fertilizer with amino acids. Russ. J. Appl. Chem. 80: 352-357.

Rai, V.K. 2002. Role of amino acids in plant responses to stresses.BiologiaPlantarum. 45 (4): 481-487.

Rhods, D., S. Handa, R.A. Bressan. 1986. Metabolic changes associated with adaptation of plant cells to water stress. Plant Physiology. 82:890-903.

Robinson, S.A., A.P. Slade, G.G. Fox, R. Phillips, R.G. Ratcliffe and G.R. Stewart. 1991. The role of glutamate dehydrogenase in plant nitrogen metabolism. Plant \& Cell Physiology. 95:509-516.

RRTC. 2018. National Rice Research Program: Final results of 2017 growing season. Sakha, Egypt.

Ullah, M. Z., M.K. Bashar, M.S.R. Bhuiyan, M. Khalequzzaman and M. J. Hasan. 2011. Interrelationship and caused-effect analysis among morpho-physiological traits in biroin rice of Bangladeshi. Int. J. Plant Breed. Genet. 5:246-254.

Van Oosten, M.A., O. Pepe, S.D. Pascale, S. Silletti and A. Maggio. 2017. The role of biostimulants and bioeffectors as alleviators of abiotic stress in crop plants. Chemical and Biological Technologies in Agriculture. 4:5.

Yakhin O.I., A.A. Lubyanov, I.A. Yakhin and P.H. Brown. 2017. Biostimulants in plant science: A global perspective. Frontiers in Plant Science. 7(2049):1-32.

Yaronskaya E., I. Vershilovskaya, Y. Poers, A.E. Alawady, N. Averina and B. Grimm. 2006. Cytokinin effects on therapy role biosynthesis and photosynthetic activity in barley seedlings. Plant. 224:700-709. 


\section{الملخص العربي}

\section{تحسين إنتاجية بعض أصناف الأرز باستخدام بعض محفزات النمو}

إبراهيم عبدالنبي طلحة ، محمد عباس جمعة،عبد الواحد محمود ندا وداليا محمد طبل

تعد المنشطات الحيوية (محفزات النمو) أحد المنتجات والتدريب في الأرز وتسجيل البيانات للصفات المدروسة علي

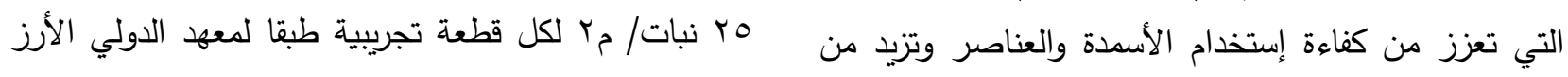

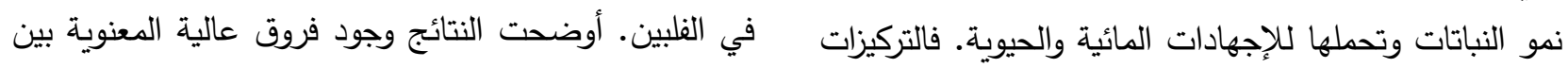
محفزات النمو وأصناف الأرز للصفات المدروسة ، ، حيث إوديث سجلت القيم المرغوبة للمحصول ومكوناته باستخدام محفز النمو Alfarid 1 Vي يليه في حين سجلت أقل القيم للمحصول ومكوناته مع معاملة الكنترول (بدون رش) أي محفز نمو. تفوق محصول الحبوب باستخدام محفز النمو علي معاملة الكنترول بـ 9 . ..rץiusid Agro

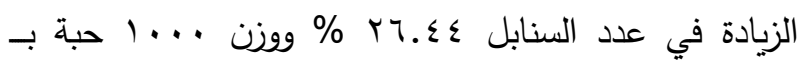

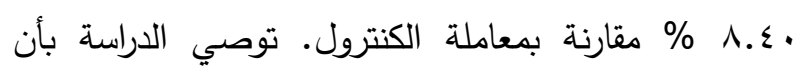

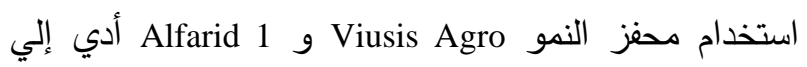
زيادة في محصول الهجينان سخا عب.r و سخا r. ... المنخفضة من هذه المواد تكون ذات كفاءة وتعطي الأداء الجيد للعمليات الحيوية داخل النبات وتسمح بإنتاجية ومنتجات ذات جودة عالية. أجريت التجربة في المزرعة البحثية لمركز البحوث والتدريب في الأرز سمطة البحوث الزراعية بسخا - معهد بحوث المحاصيل الحقلية- مركز البحوث الزراعية. تهدف التجربة إلي دراسة تأثير محفزات النمو علي صفات النمو ومحصول الحبوب والعلاقة بين محصول الحبوب ومختلف محفزات النمو للصفات المدروسة. تم تقييم تسعة أصناف أرز تحت ثلاث منظمات نمو وهي Viusid agro, Alfarid 1 and Humic plus باستخدام الري كل ثمانية أيام. المستخدم القطاعات المنشقة مرة واحدة في ثلاث مكررات حيث تم وضع منظمات النمو في القطع الرئيسية بينما تم وضع أصناف الأرز في القطع الثقية الأولي • تم تطبيق

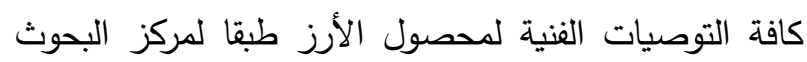

